\title{
GENETIC AND PHENOTYPIC PARAMETERS OF PRODUCTIVITY TRAITS ON THE FIRST THREE LACTATIONS IN GYR CATTLE HERDS
}

\author{
Maria do Socorro Maués Albuquerquel, Maria Armênia Ramalho de Freitas ${ }^{2}$ and Roberto Luiz Teodoro ${ }^{3}$
}

\begin{abstract}
Records of Gyr cows selected for milk production were obtained from the National Gyr Dairy Cattle Breeding Program (Embrapa/ CNPGL) and analyzed, in order to estimate genetic parameters for the first three lactations and to verify the effects of some environmental factors on milk production from 1979 to 1994 . Genetic parameters were estimated by REML with an animal model and a group of fixed effects that included classes of herd, year, season and age at calving. Milk production means and standard deviations were 2,183 kg, $707 \mathrm{~kg} ; 2,682 \mathrm{~kg}, 762 \mathrm{~kg}$ and 2,638 kg, $851 \mathrm{~kg}$, for first, second, and third lactations, respectively. Heritability estimates were $0.20,0.12$, and 0.19 for first, second, and third lactations, respectively, and repeatability was 0.44 . Genetic correlation estimates were: 0.68 between first and second lactations, 0.84 between first and third lactations and 1.0 between second and third lactations. Results confirm other research for specialized dairy breeds and firmly suggest that even in breeds of Indian origin the best time to make selection decisions is during the first lactation.
\end{abstract}

\section{INTRODUCTION}

The low productivity of Brazilian dairy herds and scarcity of specialized breeds or animal groups with good genetic potential for milk yield and adaptability to the environmental conditions of the country have been cited as reasons contributing to reduced economic efficiency of the dairy industry. The Gyr breed, due to its genetic background and adaptation allied to the increased productivity observed in these animals over the last few years, may be considered a viable alternative for dairy production in some Brazilian regions, not only as a pure breed, but also in crosses with specialized European dairy breeds.

Since 1985, the progeny test of breed selection for milk production, coordinated by Embrapa, has played a relevant role, as reflected by the considerable increase in demand for this genetic material after the first test results. Estimates of genetic and phenotypic parameters for milk yield and lactation length are important tools for the definition and evaluation of selection programs. Although several studies have been conducted on Gyr cattle over the last years, research should be intensified to identify and utilize animals with greater productive potential. The trait milk yield is considerably affected by environmental factors, which, in addition to genetic differences, are responsible for the marked variation between breeds and animals within the same breed, and between herds. Thus, it is fundamentally important to quantify sources of variation that affect dairy cow productivity so that breeding programs may be conducted properly in order to obtain a better equilibrium between genetics and environment and, con-

\footnotetext{
${ }^{\prime}$ Centro Nacional de Pesquisa de Recursos Genéticos e Biotecnológicos Cenargen-Embrapa, Caixa Postal 02372, 70770-900 Brasilia, DF, Brasil. ${ }^{2}$ Estação Experimental de Zootecnia de Ribeirão Preto IZ/CPA/SAA, Ribeirão Preto, SP, Brasil. Send correspondence to M.A.R.F. ${ }^{3}$ Embrapa Gado de Leite da Embrapa, Juiz de Fora, MG, Brasil.
}

sequently, higher productivity. Major environmental factors that affect productivity traits and genetic comparisons between breeds, strains and populations are herd, year and calving season, age at calving and management, among others. The importance of these factors on dairy herd productivity has been emphasized by many authors (Teodoro et al., 1977; Cardoso et al., 1982; Gadini, 1985; Bianchini Sobrinho, 1988; Bonganhi, 1990; Gonçalves, 1994). Some of the researchers who investigated genetic parameters of productivity traits in Gyr herds showed that variation in lactation length has been attributed predominantly to environmental factors in addition to the existence of reduced genetic merit (Verneque (1982); Benintendi et al. (1988); Mello (1994); De Bem (1996)). However, if lactation length has genetic variation and its correlation with milk yield is not low, prolongation or elimination of short lactation periods would be expected to reduce genetic variation. Lactation length and its relationship to milk yield were also studied by Magnabosco (1990), Madalena et al. (1992) and Souza et al. (1995). Economically important traits are usually associated in domestic animals, and the magnitude of this association can be determined by the genetic correlation, which measures the extent to which the same genes cause variations in two traits at the same time. When a correlation exists, it can be a very important tool in animal breeding, since it can result in improving several traits by selecting only for one of them. Genetic correlations between milk yield and different lactations have not been extensively studied in Zebu cattle. In general, most studies which investigated the relationship between milk yield and other traits, such as lactation length, have been conducted on specialized dairy breeds. Thus, the objective of the present study was to estimate genetical and environmental parameters for productivity traits during the first three lactations in Gyr herds selected for milk yield, in order to provide information that might contribute to selecting Gyr dairy cattle in Brazil. 


\section{MATERIAL AND METHODS}

Records from Gyr cows selected for milk yield were obtained from the files of the National Gyr Dairy Cattle Breeding Program (Embrapa/CNPGL). Management conditions for most herds are classified as semi-intensive whereby animals are kept predominantly on pasture during the rainy season (October-March), occasionally receiving bulk supplements (silage or sugar cane) plus concentrates and minerals. During the dry season (April-September), in addition to preserved forage animals receive mineral supplements and concentrates according to milk production. Over the last few years, use of mechanical milking has become common in some herds. Animals are milked twice a day in the presence of the calf in order to stimulate milk secretion. Calves are weaned from ten to twelve months, and their diet is complemented with bulk feed and concentrates. Artificial insemination is a technique frequently used in the herds under study, although controlled natural mounts with bulls are not excluded. Sanitary management is routinely performed with obligatory vaccinations and prophylaxis against ecto and endoparasites.

To improve the structure of the data set, the sample included at least six daughters per sire, two sires per herd, and three sets of information per herd, year, and season of calving (HYS). Each year was divided into two calving seasons, April-September (dry season) and October-March (rainy season). Age at calving was divided into six classes: A) less than 3.5 years, B) 3.5 to 4.5 years, C) 4.5 to 5.5 years, D) 5.5 to 6.5 years, E) 6.5 to 7.5 years, and F) more than 7.5 years. Thus, the working file was reduced to 1,402 records for cows sired by 83 bulls during the period of 1979 to 1994 . Only animals that had completed their first lactation were studied during their second and third lactations. Four working files were created: three contained information for each parturition order and the fourth consisted of a file for the lactations as a whole.

The traits studied were: total milk yield, lactation length and 305-day milk yield (L305) for the first, second and third lactations considered individually, and for the three lactations as a whole. Environmental effects on these traits were analyzed by the method of least squares analysis of variance using the GLM procedures of the Statistical Analysis System (SAS, 1988). Fixed effects were herd, year-season and age at calving, according to the following mathematical model:

$$
\mathrm{Y}_{\mathrm{ijklm}}=\mu+\mathrm{r}_{\mathrm{i}}+\mathrm{as}_{\mathrm{j}}+\mathrm{O}_{\mathrm{k}}+\mathrm{t}_{1}+\mathrm{e}_{\mathrm{ijklm}}
$$

where $Y_{i j k l m}=$ trait analyzed, $\mu=$ overall mean, $r_{i}=$ fixed effect of the ith herd $(i=1,2, \ldots ., 11), a s_{j}=$ fixed effect of the $\mathrm{jth}$ year-season $(\mathrm{j}=1,2, \ldots \ldots, 32), \mathrm{O}_{\mathrm{k}}=$ fixed effect of the kth class of cow's age at calving $(\mathrm{k}=1,2, \ldots \ldots, 6), \mathrm{t}_{1}=$ random effect of the lth sire $(1=1,2, \ldots . ., 41)$, and $\mathrm{e}_{\mathrm{ijk} k \mathrm{~m}}=$ random error associated with each observation. Assumptions were:

$$
\mathrm{t}_{1}=\mathrm{A} \sigma_{\mathrm{a}}^{2}, \mathrm{~V}(\mathrm{e})=\mathrm{I} \sigma_{\mathrm{e}}^{2}, \operatorname{Cov}(\mu, \mathrm{e})=0 .
$$

The (co)variance components needed to estimate the genetic parameters for the variables studied were obtained by restricted maximum likelihood in a derivativefree procedure (DFREML) using the multiple trait derivative-free restricted maximum likelihood (MTDFREML) software developed by Boldman et al. (1993). Univariate analyses using an animal model were performed to estimate heritability. The following animal model in the matrix form was used for the analyses:

$$
\mathrm{Y}=\mathrm{X} \beta+\mathrm{Zv}+\mathrm{e}
$$

where $\mathrm{Y}=$ information vector of the third and first lactations, $\beta=$ fixed effect vector, $X=$ incidence matrix that associates $\beta$ with $X, v=$ random effect vector [genetic additive $\left(\mathrm{v}_{1}\right)$ and permanent effect $\left.\left(\mathrm{v}_{2}\right)\right], \mathrm{Z}=$ incidence matrix that associates $\mathrm{v}$ elements with $\mathrm{Y}$, and $\mathrm{e}=$ residual random effect vector. Assumptions were as follows:

$$
\begin{aligned}
& \mathrm{V}\left(v_{1}\right)=\mathrm{G}=A \sigma_{\mathrm{a}}^{2} \\
& \mathrm{~V}\left(v_{2}\right)=\sigma_{\mathrm{p}}^{2} \\
& \mathrm{~V}(\mathrm{e})=\mathrm{R}=\mathrm{I} \sigma_{\mathrm{e}}^{2} \\
& \operatorname{Cov}\left(v, \mathrm{e}^{\prime}\right)=0
\end{aligned}
$$

They can be represented as:

$$
\mathrm{R}\left[\begin{array}{c}
\beta \\
\mathrm{v}_{1} \\
\mathrm{v}_{2} \\
\mathrm{e}
\end{array}\right]=\left[\begin{array}{c}
\mathrm{X} \beta \\
0 \\
0 \\
0
\end{array}\right]
$$

Genetic and environmental correlations between the first three lactations were calculated by bivariate analyses to determine differences between the first and second lactations as well as the first and third and second and third. Phenotypic correlations were also estimated:

$$
r_{\mathrm{p}}=\mathrm{h}_{\mathrm{x}} \mathrm{h}_{\mathrm{y}} r_{\mathrm{A}}+\mathrm{e}_{\mathrm{x}} \mathrm{e}_{\mathrm{y}} r_{\mathrm{E}}
$$

where $r_{\mathrm{p}}=$ phenotypic correlation, $\mathrm{h}_{\mathrm{x}}=$ heritability of the first trait, $\mathrm{h}_{\mathrm{y}}=$ heritability of the second trait, $r_{\mathrm{A}}=$ genetic correlation between the first and second traits, $\mathrm{e}_{\mathrm{x}}=$ environmental variance of the first trait, $\mathrm{e}_{\mathrm{y}}=$ environmental variance of the second trait, and $r_{\mathrm{E}}=$ environmental correlation between the first and second traits. Records containing information on all lactations were used to estimate repeatability, with permanent cow effects being included in the model.

\section{RESULTS AND DISCUSSION}

Mean overall milk yield and mean lactation length per herd ranged from 1172 to $3205 \mathrm{~kg}$ and 232 to 333 days in the first lactation, 2165 to $3791 \mathrm{~kg}$ and 267 to 330 days 
in the second lactation, and 2166 to $3991 \mathrm{~kg}$ and 263 to 334 days in the third lactation. These values indicate that most herds considered in the present study had mean milk yields and lactation lengths close to those reported in the literature for the same breed. It was observed that increased milk yield in some herds was not associated with prolonged lactation length, suggesting an effect of selection within and between herds performed over the years in an attempt to obtain more productive animals. With respect to the records for each lactation, there was a 50\% reduction in records from the first to the second lactation, a $49 \%$ reduction from the second to the third, and a $75 \%$ reduction from the first to the third, i.e., only $25 \%$ of the records continued to be available up to the third lactation. This tendency is similar to that reported by Tong et al. (1979) and Meyer (1984). The overall mean estimated for the lactations as a whole was $2456 \pm 141 \mathrm{~kg}$, a value similar to those reported by many authors for the same breed. Regarding estimated means and standard errors per herd (Figure 1), in general milk yield tended to moderately increase from the first to second lactation with a slight decrease observed in some herds. From the second to the third lactation, there was a slight reduction in milk yield in three herds and an increase in four others. The largest mean milk yields were obtained for herd 7 for the three lactations studied, and the lowest were obtained for the first lactation of herd 11 and for the second and third lactations of herd 8 . Differences in yield between herds were expected, due to variations in the general environment, management, nutritional aspects and sanitation problems.

Estimated mean milk yields and their standard errors (SEM) for the first three individual lactations are presented in Table I. Figure 2 shows the change in milk yield over the first three lactations. Among the effects included in the model, year and season of calving, herd and sire were significant $(\mathrm{P}<0.01)$ for the first lactation. Herd, sire, and age at calving were significant $(\mathrm{P}<0.01)$ during the second lactation and herd $(\mathrm{P}<0.01)$, year and season of calving and sire $(\mathrm{P}<0.05)$ were significant during the third lactation. Analysis of variance of the three lactations is illustrated in Table II. In this analysis, year and season effects were studied jointly.

Estimates of genetic additive variance components $\left(\sigma_{\mathrm{a}}^{2}\right)$ and environment $\left(\sigma_{\mathrm{e}}^{2}\right)$, as well as genetic and phenotypic correlations between the three lactations obtained by univariate and bivariate analyses are presented in Table III. A reduction in additive genetic variance $\left(\sigma_{a}^{2}\right)$ was observed from the first to the second lactation, and an increase was observed in the third compared to the first two. Residual variance analysis showed a small increase with advancing lactations, although the reduced number of observations during the third lactation did not permit definitive conclusions about the values obtained.

Heritability estimates were obtained by univariate analysis for the three individual lactations using the same procedure. Values for milk yield were $0.20,0.12$ and 0.19 , respectively. In the results obtained by DFREML, estimates decreased from the first to the second lactation and then

Table I - Number of animals (N), estimated mean milk yields up to 305 days and standard errors of the mean (SEM) for the three lactations studied.

\begin{tabular}{llll|}
\hline Milk yield & N & Mean & SEM \\
\hline First lactation & 797 & 2204 & 289 \\
Second lactation & 399 & 2699 & 208 \\
Third lactation & 206 & 2691 & 122 \\
\hline Total & 1402 & 2457 & 141 \\
\hline
\end{tabular}

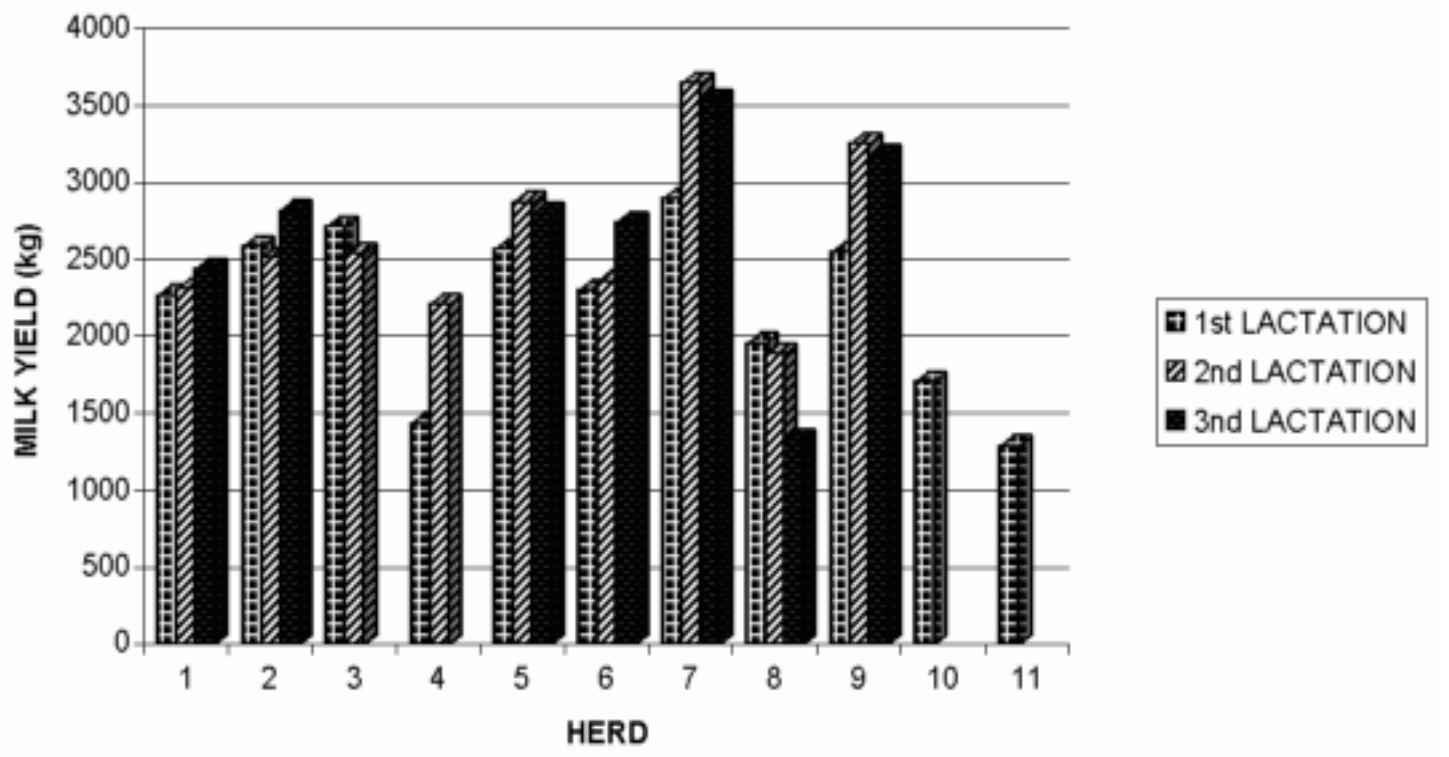

Figure 1 - Estimated mean milk yields up to 305 days for the first three lactations per herd. 


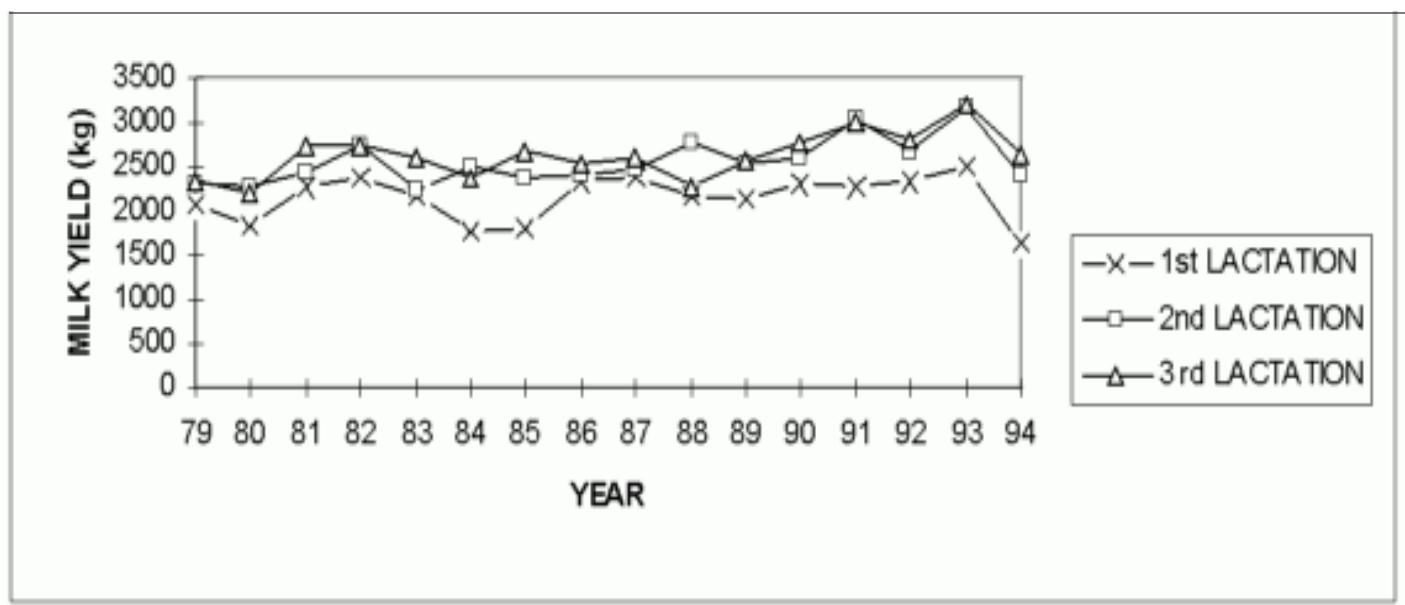

Figure 2 - Mean milk yield of Gyr cows during the first three lactations from 1979 to 1994.

Table II - Sources of variation, degrees of freedom (d.f.) and mean squares (MS) for the first three lactations of Gyr cows.

\begin{tabular}{|c|c|c|c|c|c|c|}
\hline \multirow[t]{2}{*}{ Source of variation } & \multicolumn{2}{|c|}{ 1st lactation } & \multicolumn{2}{|c|}{ 2nd lactation } & \multicolumn{2}{|c|}{ 3rd lactation } \\
\hline & d.f. & MS & df. & MS & d.f. & MS \\
\hline Sire & 40 & $622865 * *$ & 30 & $628007 * *$ & 24 & $690234 *$ \\
\hline Herd & 10 & $3167760 * *$ & 9 & $1649025 * *$ & 6 & $1461018 * *$ \\
\hline Year x season & 30 & $985366^{* *}$ & 29 & 452048 & 26 & $706110^{*}$ \\
\hline Age class & 4 & 520023 & 4 & $12977389 * *$ & 3 & 773188 \\
\hline Error & 712 & 323526 & 326 & 340934 & 146 & 427266 \\
\hline Total & 796 & & 398 & & 205 & \\
\hline
\end{tabular}

$(\mathrm{P}<0.01)^{* *}(\mathrm{P}<0.05)^{*}$.

Table III - Additive genetic variance components $\left(\sigma_{\mathrm{a}}^{2}\right)$, residue components $\left(\sigma^{2}\right)$ and genetical $\left(r_{\mathrm{a}}\right)$ and phenotypical $\left(r_{\mathrm{p}}\right)$ correlations between the first three lactations of Gyr cows using univariate and bivariate analyses.

\begin{tabular}{|lccc|}
\hline Milk yield & $\sigma_{\mathrm{a}}^{2}$ & $\sigma_{\mathrm{e}}^{2}$ & $\mathrm{~h}^{2}$ \\
\hline First lactation & 67690 & 275345 & 0.20 \\
Second lactation & 45283 & 323428 & 0.12 \\
Third lactation & 91702 & 379378 & 0.19 \\
\hline
\end{tabular}

$r_{a 12}=0.62 r_{a 13}=0.84 r_{a 23}=1.0 ; r_{p 12}=0.34 r_{p 13}=0.20 r_{p 23}=0.34$.

increased from the second to the third. A similar trend was observed by Meyer (1984) and Swalve and Van Vleck (1987), who studied the same traits in specialized dairy breeds. Beaumont (1989) obtained results that also confirmed a trend of reduced heritability from the first to the second lactation and a decrease in the second lactation compared to the third, suggesting that the population in question may be experiencing the effects of selection.

When the lactations were analyzed jointly, heritability and repeatability estimates were 0.15 and 0.44 for total milk yield and 0.08 and 0.31 for lactation length.
Heritability estimates were 0.09 for first lactation length and 0.11 for second lactation length when the lactations were analyzed separately. These values agreed with those reported in the literature. Genetic correlations for milk yield calculated by bivariate analysis were 0.62 between the first and second, 0.84 between the first and third and 1.0 between the second and third. These results again confirmed that genetic correlation estimates of milk yield between lactations are usually high. It is very important to emphasize that the value of almost one obtained for correlation between second and third lactations may be attributed to the reduced number of data for this third lactation. In general, values obtained in this study do not differ from those reported by several other authors, who obtained values higher than 0.80 between first and second lactations and values of 1.0 between the second and third. Most results indicate that animal performance during various lactations is influenced by the same genes with minimum variation; therefore, the yield obtained during the first lactation may represent an efficient criterion for selection. Although Brazilian farmers commonly wait until the second lactation to make culling decisions of Zebu herds and their crosses, 
results of the present study demonstrate that the procedure adopted for specialized dairy breeds can be applied with reasonable safety to Zebu breeds, resulting in higher profits for the dairy industry due to reduced costs of maintaining unproductive animals on the farm.

\section{CONCLUSIONS}

Based on the results obtained, it appears that total milk yield during the different lactations was not associated with the prolonged lactations which suggests the effect of selection in the search for more productive animals. Heritabilities for milk yield and lactation length for the lactations studied indicated that only a relatively small part of the variation observed in these traits is due to the additive effect of genes and use of tested sires together with improved animal management is indispensable to obtain genetic gains in this population. Genetic correlations between first and second lactations, between first and third lactations and between second and third lactations suggest that the same genes influence these traits and that selection may be practiced at first lactation even in Zebu breeds.

\section{ACKNOWLEDGMENTS}

Publication supported by FAPESP. M.A.R.F. and R.L.T. are recipients of CNPq fellowships.

\section{RESUMO}

Registros de vacas da raça Gir selecionadas para produção de leite, oriundos do Programa Nacional de Melhoramento do Gir Leiteiro (EMBRAPA/CNPGL), no período de 1979 a 1994 foram analisados visando estimar os parâmetros genéticos para as três primeiras lactações, assim como verificar o efeito de alguns fatores de meio sobre estas características. Os parâmetros genéticos foram estimados sob REML com um modelo animal e um grupo de efeitos fixos que incluía rebanho (H), ano-estação (YS) e idade da vaca ao parto em classes. As médias da produção de leite e desviospadrão foram $2.183 \mathrm{~kg}$ e $707 \mathrm{~kg}$ para a primeira lactação, $2.682 \mathrm{~kg}$ e $762 \mathrm{~kg}$ para a segunda lactação e $2.638 \mathrm{~kg}$ e $851 \mathrm{~kg}$ para a terceira lactação. Para a duração da lactação estas médias variaram de 232 a 334 dias. As estimativas de herdabilidades foram 0,20;0,12 e 0,19 para a primeira, segunda e terceira lactações, respectivamente, e a repetibilidade foi 0,44 . As correlações genéticas estimadas foram: 0,68 entre a primeira e a segunda lactação, 0,84 entre a primeira e a terceira e 1,0 entre a segunda e a terceira. Os resultados confirmam os citados pela literatura para as raças leiteiras especializadas e sugerem, com certa segurança, que mesmo nas raças de origem indiana pode-se praticar seleção com base na primeira lactação.

\section{REFERENCES}

Beaumont, C. (1989). Restricted maximum likehood estimation of genetic parameters for the first three lactations in the Montbeliarde dairy cattle breed. Genet. Sel. Evol. 21: 493-506.

Benintendi, R.P., Cardoso, V.L., Freitas, M.A.R., Bonilha Neto, L.M., Guilhermino, M.M. and Pires, F.L. (1988). Índices zootécnicos de um rebanho da raça Gir em seleção para produção de leite. Bol. Ind. Anim. 45: 119-131.

Bianchini Sobrinho, E. (1988). Estimativa da produção total de leite de vacas da raça Gir, baseada em controles semanais, quinzenais, mensais e bimestrais, obtenção de fatores multiplicativos. Livre-Docência, thesis, FCAV/UNESP, Jaboticabal.

Boldman, K.G., Kriese, L.A., Van Vleck, L.D. and Kachan, S.D. (1993). A Manual for Use for MTDFREML. A Set of Programs to Obtain Estimates of Variance and Covariances [DRAFT]. Department of Agriculture. Agricultural Research Service, Lincoln, pp. 120.

Bonganhi, I.A. (1990). Avaliação de touros e vacas por diferentes métodos de estimação da produção total de leite de vacas da raça Gir, utilizando diferentes intervalos entre controles. Master's thesis, FCAVJ/UNESP, Jaboticabal.

Cardoso, V.L., Pires, F.L., Freitas, M.A.R., Benintendi, R.P. and Oliveira, A.A.D. (1982). Aspectos da produção de leite em rebanho da raça Gir em seleção leiteira. In: Reunião Anual da Sociedade Brasileira de Zootecnia, Piracicaba, SP. Piracicaba, SBZ, Anais. pp. 202.

De Bem, I.A.B. (1996). Determinação do coeficiente de consanguinidade de zebuínos leiteiros da raça Gir e sua relação com as características produtivas e reprodutivas. Doctoral thesis, UNESP, Botucatu.

Gadini, C.H. (1985). Influências genéticas e ambientais sobre a curva de lactação de um rebanho Gir. Master's thesis, FMRP/USP, Ribeirão Preto.

Gonçalves, T.M. (1994). Estudo da curva de lactação de vacas da raça Gir. Master's thesis, Universidade Federal de Viçosa, Viçosa.

Madalena, F.E., Lemos, A.M. and Teodoro, R.L. (1992). Consequences of removing the variation in lactation length on the evaluation of dairy cattle breeds and crosses. Braz. J. Genet. 15: 585-593.

Magnabosco, C.U. (1990). Estimativa da mudança genética na produção de leite em um rebanho da raça Gir. Master's thesis, Faculdade de Medicina de Ribeirão Preto, Universidade de São Paulo, Ribeirão Preto.

Mello, A.A. (1994). Resposta à seleção em características de importância econômica em um rebanho da raça Gir. Master's thesis, Universidade Federal de Minas Gerais, Belo Horizonte.

Meyer, K. (1984). Estimates of genetic parameters for milk and fat yields for the first three lactations in British Friesian cows. Anim. Prod. 38: 313-322.

Queiroz, S.A. (1992). Estudo da endogamia na raça Gir. Master's thesis, Faculdade de Medicina de Ribeirão Preto da Universidade de São Paulo, Ribeirão Preto.

SAS Institute Inc. (1998). SAS User's Guide: Statistics. 5th edn. Cary, NC. Souza, E.M., Milagres, J.C., Martinez, M.L., Regazzi, J. and Silva, M.A. (1995). Efeitos de fatores genéticos e de meio ambiente sobre a duração do período de lactação em rebanhos de Gir Leiteiro. Rev. Soc. Bras. Zootec. 24: 150-163.

Swalve, H. and Van Vleck, L.D. (1987). Estimation of genetic (Co) variances for milk yield in first three lactations using an animal model and restricted maximum likelihood. J. Dairy Sci. 70: 842-849.

Teodoro, R.L., Pereira, J.C.C., Sampaio, J.B.M. and Lemos, A.M. (1977). Fatores ambientais que influem sobre a produção de leite em um rebanho Gir. In: Encontro de Pesquisa do NAP, 6, UFMG, Belo Horizonte. Anais. pp. 89.

Tong, A.K.W., Kennedy, B.W. and Moxley, J.E. (1979). Heritabilities and genetic correlations for first three lactations from records subject to culling. J. Dairy Sci. 62: 1784-1790.

Verneque, R.S. (1982). Fatores genéticos e de meio e características produtivas de um rebanho Gir leiteiro. Master's thesis, UFV, Viçosa.

(Received May 4, 1998) 
